\title{
Protein quality of some unusual protein foodstuffs. Studies on the African locust-bean seed (Parkia filicoidea Welw.)
}

\author{
By B. L. FETUGA, G. M. BABATUNDE AND V. A. OYENUGA \\ Department of Animal Science, University of Ibadan, Ibadan, Nigeria
}

(Received I3 April 1973 - Accepted 2 October 1973)

\begin{abstract}
I. The proximate composition, amino acid composition and the quality of the protein of the African locust-bean (Parkia filicoidea Welw.) seed, seed with pulp, and various processed forms, with or without amino acid supplementation, were assessed.

2. The crude protein content of the locust-bean seed was $303 \mathrm{~g} / \mathrm{kg}$ and the crude fibre content was $12 \mathrm{r} / \mathrm{kg}$.

3. The seeds contained (mg/g protein): 67 lysine, 6.1 methionine and 8.9 tryptophan.

4. Diets containing $100 \mathrm{~g}$ protein $/ \mathrm{kg}$ supplied by the seed did not support growth in rats, demonstrating that the protein was of poor quality.

5. Utilization of the protein of locust-bean seeds was improved by cooking, and by removal of the tough leathery outer testa of the seeds.

6. Supplementation with methionine alone resulted in positive growth and a very substantial increase in protein values.

7. Supplements of methionine and tryptophan caused further improvement in protein quality and increased the growth of rats to almost that obtained with whole egg.
\end{abstract}

In Nigeria, as in all other developing countries, there is a general shortage of protein, particularly of animal proteins, in the diet.

The livestock situation has not improved much in recent times because of a lack of basic information on the available feeding-stuffs, which has mitigated against the use of these feeding-stuffs in balanced and economical rations for farm stock or in dietary mixtures for feeding the vulnerable groups of people. Cheap sources of good-quality proteins for livestock feeding are scarce, and this has necessitated a survey of the potentials of sources hitherto not much used.

The studies reported here are part of a series of systematic investigations which have been undertaken to evaluate nutritionally a wide range of protein foodstuffs not commonly used but which may ultimately be used on a large scale if found to be of high nutritional value.

The African locust bean (Parkia filicoidea Welw.) is a spreading tree of medium size, with compound leaves and numerous leaflets. The fruits comprise bunches of pods which vary between 125 and $275 \mathrm{~mm}$ in length and contain a yellow, dry, powdery pulp, in which are embedded several dark brown or black seeds. It is widely distributed in the natural grassland of the northern states and in derived savannah zones of the western states of Nigeria.

The yellow mealy pulp is sweet to the taste and is made into a valuable carbohydrate food. The seeds are sometimes boiled for $24 \mathrm{~h}$ and made into cakes. The seed and pulp have both been used as food for pigs in the dry season in northern Nigeria, when other protein sources are scarce, though their true value is not known. Also, all 
parts of the fruit, including the pod, the mealy material and seeds, are recognized as valuable cattle foods. For man, they are used essentially as condiments in many Nigerian and other African diets.

\section{EXPERIMENTAL}

\section{Origin, preparation and storage of samples}

The African locust-bean-seed samples were obtained direct from local farmers around Iseyin and Oyo in western Nigeria. Some of the samples had been removed already from the pods and washed clean of the yellow pulp. These are the samples designated 'bean seed'. The only laboratory treatment given to them was cooking in boiling water for $3 \mathrm{~h}$, sun-drying and then grinding into a fine powder which passed through a 30 mesh sieve. The sample designated 'bean seed with pulp' comprised the cooked seed and yellow, sweetish pulp $(75: 25, \mathrm{w} / \mathrm{w})$.

\section{Expt $\mathrm{I}$}

In this experiment, the proximate composition, total amino acid composition and protein quality of samples of the bean seed and bean seed with pulp were compared with those of freeze-dried, diethyl ether-extracted whole egg and casein.

Proximate analysis. All analyses were done on air-dried samples. Moisture, nitrogen, diethyl ether extract, crude fibre, ash, calcium and phosphorus contents were determined by the methods of the Association of Official Analytical Chemists (1970). The amount of $\mathrm{N}$-free extract was obtained by difference. The other minerals (magnesium, manganese, sodium, zinc, copper and iron) contents were determined with a PerkinElmer atomic absorption spectrophotometer (Model 290), after wet-ashing with a mixture of nitric, perchloric, and sulphuric acids. Energy content was determined with a Gallenkamp oxygen ballistic bomb calorimeter (A. Gallenkamp and Co. Ltd, London).

Amino acid composition. The total amino acid composition of the samples was determined by the column chromatographic technique using the automated HitachiPerkin-Elmer amino acid analyser (Model KLA-3B; Hitachi Ltd, Tokyo, Japan) after acid hydrolysis of $100 \mathrm{mg}$ of each sample with $10 \mathrm{ml} 6 \mathrm{M}-\mathrm{HCl}$ at I $10^{\circ}$ for $24 \mathrm{~h}$. Tryptophan was determined chemically by the method of Miller (1967).

Biological evaluation of protein quality. Forty male albino rats of the Wistar strain, weaned at $2 \mathrm{I}$ d, were obtained from the disease-free stock of the Veterinary Science Department, University of Ibadan, and reared on a balanced commercial stock diet (Pfizer Livestock Feed Ltd, Ikeja, Nigeria) until they were $30 \mathrm{~d}$ old, when they were weighed to the nearest $0.1 \mathrm{~g}$ and allocated on the basis of weight and litter origin to five groups of eight rats each. They were individually housed in perforated Perspex cages with facilities for separate faecal and urinary collection, and were used to determine protein efficiency ratio (PER), net protein utilization $\left(\mathrm{NPU}_{\mathrm{st}}\right)$, biological value (Bv), and apparent and true digestibility of the bean-seed samples and of freeze-dried diethyl ether-extracted egg and nutritional casein (British Drug Houses Ltd).

The composition of the basal diet is shown in Table 1 . The protein sources to be evaluated were added at the expense of maize starch to give $100 \mathrm{~g}$ crude protein $/ \mathrm{kg}$ 


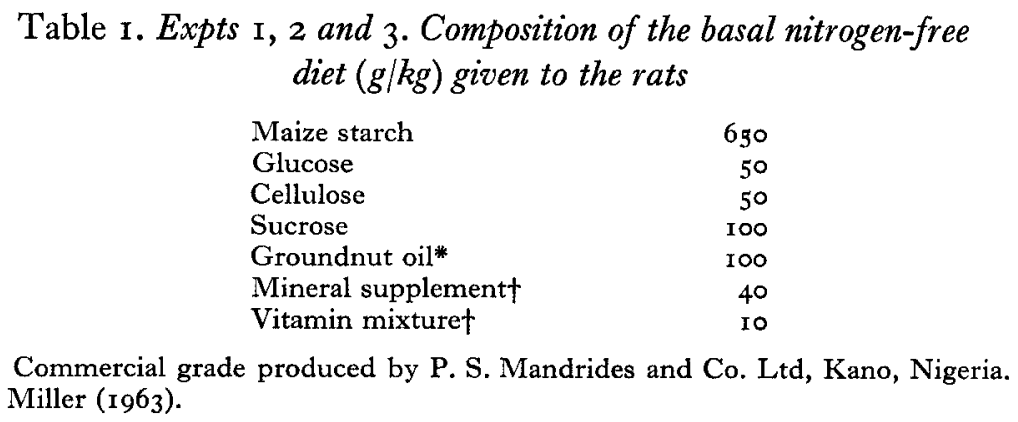

diet. Mixing was done initially in a 51 glass beaker and then in a motorized laboratory rotary mixer for $\mathrm{I}^{-20} \mathrm{~min}$. Homogeneity of the diet was checked by determining the $\mathrm{N}$ content of each diet in duplicate immediately after mixing and in the middle of the experimental period.

One group of eight rats was given the $\mathrm{N}$-free basal diet (Table $\mathrm{r}$ ), and the remaining four groups were randomly allocated to the test diets. The assigned $\mathrm{N}$-free and experimental diets and water were offered $a d l i b$. Records were kept of the weight gains and total food intake. The protein and $\mathrm{N}$ consumed were calculated from the total food intake, and the protein or $\mathrm{N}$ content of the test diets as determined by the microKjeldahl method.

For the determination of biological values, and apparent and true digestibilities, the rats were given the test diets for $7 \mathrm{~d}$, then faeces and urine were collected from four rats on each of the test diets, for a further period of $7 \mathrm{~d}$. The urine from each cage was collected in small urine cups containing $3 \mathrm{ml}$ sulphuric acid (ro g/l), each day's collection being stored in screw-capped bottles at $-5^{\circ}$. Additional precautions against urinary losses were taken by fixing absorbent papers to the corners of the cages and between the resting stage and the gutters, and these were later washed with sulphuric acid ( $1 \circ \mathrm{g} / \mathrm{l})$ and added to the stored sample. Faecal samples were collected daily, bulked for each rat at the end of the collection period, weighed, dried and ground. Duplicate samples of urine and faeces were taken for $\mathrm{N}$ determination. The $\mathrm{N}$ content of each diet was also determined and the total $\mathrm{N}$ intake during the $7 \mathrm{~d}$ collection period was calculated using this value and that of the recorded dietary intake during this period. BV and apparent and true digestibilities were calculated using the formula given by the (US) National Academy of Sciences/National Research Council ( 1963 ).

For the determination of PER and NPU, the remaining four rats in each group were weighed after ro $\mathrm{d}$ of dietary treatment and killed with chloroform. Total food intake in ro $\mathrm{d}$ was also measured and this value and the determined crude protein content of the diet were used to calculate the amount of protein consumed during test. The PER was calculated from these results using the formula given by the (US) National Academy of Sciences/National Research Council (1963).

The carcasses of the rats were dried in a hot-air circulation oven at $85^{\circ}$, after incisions had been made into the skull, thoracic and body cavities. The dried carcasses were digested for $\mathrm{N}$ determination by a method based on that of Rippon (1959); the 
only modification was that it was found unnecessary to autoclave the carcass digest, as complete disintegration occurred when distilled-water was added to a slurry of the dried carcass in $200 \mathrm{ml}$ concentrated sulphuric acid. The resultant dark-red solution was made up to $500 \mathrm{ml}$ and duplicate $25 \mathrm{ml}$ samples were taken for $\mathrm{N}$ determination. The NPU values were calculated using the revised equation of Bender \& Doell (1957).

\section{Expt 2}

The object of this experiment was to test the effect of the removal of the main source of fibre in the African locust bean on the utilization of its protein. The effects of cooking and fermentation were also examined. The samples selected represented the different stages in the local processing of this foodstuff.

Local processing procedure. The local processing procedure leading to the fermentation of the African locust-bean seed involves the following steps: ( $\mathrm{I}$ ) the seeds are cooked for between 4 and $6 \mathrm{~h}$, cooking being stopped when testa can be removed by rubbing between two fingers; (2) the seeds are placed in mortars and gently pounded to remove the tough leathery testa; (3) the seeds are strained in baskets or calabashes to separate the testa from the whitish endosperm and (4) the shelled seeds are then returned to pots and cooked for a further $30 \mathrm{~min}$, after which they are stacked in baskets and placed in sealed sacks to ferment. On the basis of this processing procedure, the African locust-bean seed was evaluated in the following forms: (1) raw bean seed with testa; (2) cooked bean seed with testa; (3) raw bean seed without testa; (4) cooked bean seed without testa and (5) fermented bean seed.

Experiments with rats. Fifty-six rats of the same breed, sex and strain as those used in Expt I were used in this experiment, there being eight rats/treatment. The different forms of the locust bean and the diethyl ether-extracted whole egg were added to the basal diet (Table I) at the expense of maize starch to give diets containing roo g crude protein $/ \mathrm{kg}$. The unmodified basal diet was used as the $\mathrm{N}$-free diet. Feeding, routine management, length of experimental period and measurements were the same as those described for Expt r.

\section{Expt 3}

The basal diet and experimental methods were the same as those used in Expt I, the only difference was that various combinations of pure, synthetic DL-methionine and L-tryptophan were added to the diets. Seven preparations of the African locust bean were evaluated as protein sources for rats, with and without supplements of amino acids as follows: (I) beans cooked without testa; (2) beans cooked without testa, with the addition of $2.5 \mathrm{~g}$ DL-methionine $/ \mathrm{kg}$; (3) beans cooked without testa, with $2.5 \mathrm{~g}$ DL-methionine $+0.8 \mathrm{~g}$ L-tryptophan $/ \mathrm{kg}$; (4) beans cooked with testa; (5) beens cooked with testa $+2.5 \mathrm{~g}$ DL-methionine/kg; $(6)$ beans cooked with testa, with $2.5 \mathrm{~g}$ DL-methionine $+0.8 \mathrm{~g}$ L-tryptophan $/ \mathrm{kg}$ and (7) beans raw, without testa, with $2.5 \mathrm{~g}$ DL-methionine $+0.8 \mathrm{~g}$ L-tryptophan $/ \mathrm{kg}$.

There were eight rats/treatment and an additional group of eight rats were given a $\mathrm{N}$-free diet, making a total of sixty-four rats. All results were analysed by analysis of variance (Steel \& Torrie, r960). Treatment means were compared by Duncan's (I955) multiple range test. 
Table 2. Chemical composition (per kg dry matter) of different forms of the African locust bean

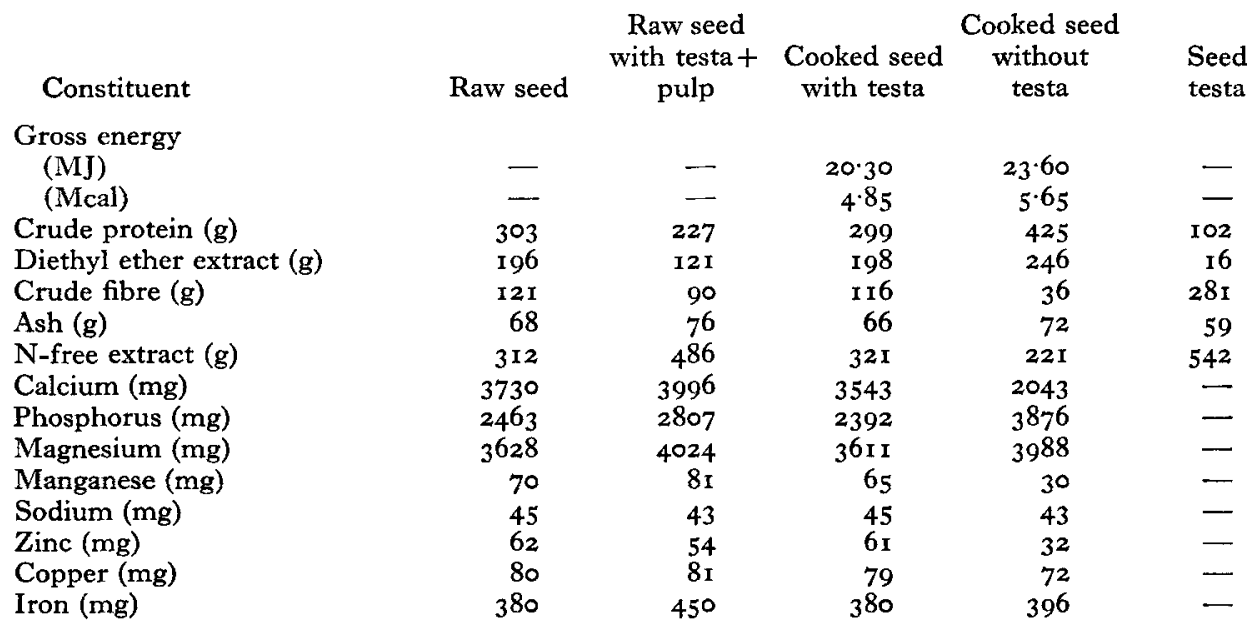

RESULTS

Expt I

Proximate composition. Table 2 shows the proximate composition of the African locust-bean seed, of the seed with pulp, and of the bean-seed testa. The high crude fibre contents, particularly of the testa, are of interest.

Amino acid composition. The amino acid composition of the locust-bean seed is compared in Table 3 with values obtained in our laboratory for other oilseeds in common use. The locust-bean seed is rich in lysine, containing more than any other oilseed protein analysed; only the soya-bean protein has a similar lysine content. Locust-bean seed contains 6. I mg methionine/g protein $(\mathrm{N} \times 6.25)$ which is only about half the amount in cashewnut and cottonseed meals. It contains more cystine than any of the other sources analysed and its total sulphur amino acid (methionine+ cystine) content is higher than that of groundnut meal but lower than that of soya-bean meal, cottonseed meal or cashewnut meal. The tryptophan content is lower than that of any of the other oilseed proteins listed above. Compared with a standard reference protein (whole hen's egg), the locust-bean seed, on a weight basis, contains slightly more arginine, histidine and proline, and much more glutamic acid than whole egg. Methionine and tryptophan contents relative to lysine content were low, $9 \cdot 2$ and $10.2 \%$ respectively, compared with 31.9 and $23.2 \%$ respectively in whole egg. A total sulphur amino acid value of $38.0 \%$ relative to lysine was found in the locust-bean seed compared with $83.0 \%$ in egg. Other essential amino acids such as isoleucine, phenylalanine, threonine and tyrosine were also present in greater proportions relative to lysine in egg than in the locust-bean seed.

Protein quality. Values for protein quality of the locust-bean seed, locust-bean seed with pulp, freeze-dried, diethyl ether-extracted whole egg and casein are shown in Table 4. Apparent and true digestibilities of the locust-bean seed and of the seed with 
Table 3. Expt I. Amino acid composition ( $m g / g$ protein)* of the African locust-bean seed, whole hen's egg and other oilseed protein sources in common use

\begin{tabular}{|c|c|c|c|c|c|c|}
\hline Amino acids: & $\begin{array}{c}\text { African } \\
\text { locust-bean } \\
\text { meal }\end{array}$ & $\begin{array}{c}\text { Groundnut } \\
\text { meal }\end{array}$ & $\begin{array}{c}\text { Cashewnut } \\
\text { meal }\end{array}$ & $\begin{array}{c}\text { Soya-bean } \\
\text { meal }\end{array}$ & $\begin{array}{c}\text { Cottonseed } \\
\text { meal }\end{array}$ & $\begin{array}{c}\text { Whole } \\
\text { egg }\end{array}$ \\
\hline Arginine & $66 \cdot 6$ & 123.0 & 107.0 & 743 & 123.7 & $6 I \cdot 0$ \\
\hline Histidine & 29.9 & 30.4 & 20.6 & 23.5 & $3 \mathbf{I} \cdot 3$ & $24 \cdot 3$ \\
\hline Isoleucine & $36 \cdot 0$ & $35 \cdot 8$ & $38 \cdot 6$ & $46 \cdot I$ & 34.6 & $62 \cdot 9$ \\
\hline Leucine & 69.0 & 70.9 & $65 \cdot 1$ & $78 \cdot I$ & $65 \cdot 3$ & $88 \cdot 2$ \\
\hline Lysine & $66 \cdot 8$ & 39.0 & 40.4 & $61 \cdot 0$ & $48 \cdot 9$ & $60 \cdot 8$ \\
\hline Methionine & $6 \cdot x$ & 9. I & $14 \cdot 0$ & 13.5 & 12.7 & $33 \cdot 6$ \\
\hline Cystine & 19.2 & II. 4 & I $7 \cdot 8$ & $16 \cdot 2$ & $12 \cdot 2$ & $24 \cdot 3$ \\
\hline Phenylalanine & 44.0 & $56 \cdot 0$ & $38 \cdot 9$ & 55.0 & $5^{6 \cdot 9}$ & $5^{6 \cdot 3}$ \\
\hline Tyrosine & 35.7 & $43 \cdot 4$ & 23.7 & $35 \cdot 4$ & $31 \cdot 7$ & $4 I \cdot 6$ \\
\hline Threonine & $33 \cdot 3$ & 30.4 & $3 \mathrm{I} \cdot 0$ & $38 \cdot 0$ & 35.9 & $51 \cdot 2$ \\
\hline Tryptophan & 8.9 & 1277 & 13.7 & $12 \cdot 6$ & I3. 8 & $16 \cdot 2$ \\
\hline Valine & $4 \pi \cdot 6$ & $42 \cdot 7$ & $58 \cdot 0$ & $52 \cdot 4$ & $49 \cdot 0$ & $68 \cdot 5$ \\
\hline Alanine & 45.0 & $4 I \cdot 9$ & 37.0 & $46 \cdot I$ & $42 \cdot 4$ & $59 \cdot 2$ \\
\hline Aspartic acid & $89 \cdot 1$ & 118.2 & 92.0 & II 4 I & $98 \cdot 4$ & $90 \cdot 2$ \\
\hline Glutamic acid & 174.4 & $2 \mathrm{II} \cdot 2$ & 1874 & I 840 & 2134 & $127 \cdot 4$ \\
\hline Proline & 54.7 & 50.6 & $37 \cdot 2$ & $52 \cdot 0$ & $46 \cdot 0$ & $4 \pi \cdot 6$ \\
\hline Serine & $49 \cdot 8$ & $53 \cdot 3$ & 47.6 & $53 \cdot 2$ & $5 I \cdot 6$ & $76 \cdot 5$ \\
\hline Glycine & $45 \cdot 4$ & 63.0 & 46.0 & 45.2 & $45^{6} 6$ & $33 \cdot I$ \\
\hline
\end{tabular}

Table 4. Expt 1. Protein quality of the African locust bean compared with that of freezedried, diethyl ether-extracted whole egg and of casein in diets given to rats

\begin{tabular}{|c|c|c|c|c|c|}
\hline \multicolumn{6}{|c|}{ Locust bean } \\
\hline & Seed & Seed + pulp & Egg & Casein & SE of mean \\
\hline Wt gained in so $\mathrm{d}(\mathrm{g})$ & $-9 \cdot 6$ & $-10 \cdot 1$ & $26 \cdot 8$ & $18 \cdot 3$ & $3 \cdot 14$ \\
\hline Food intake in ro $d(\mathrm{~g})$ & $3 I \cdot 7$ & $37 \cdot 2$ & $72 \cdot 7$ & $67 \cdot 6$ & $2 \cdot 46$ \\
\hline Protein intake in ro $\mathrm{d}(\mathrm{g})$ & 3.06 & 3.98 & $6 \cdot 78$ & 6.64 & $I \cdot 29$ \\
\hline $\begin{array}{l}\text { Carcass nitrogen content: } \\
\text { (g) } \\
\text { (mg/g live wt) }\end{array}$ & $\begin{array}{l}I \cdot 4 I \\
28 \cdot 3\end{array}$ & $\begin{array}{l}1 \cdot 42 \\
28 \cdot 3\end{array}$ & $\begin{array}{l}2 \cdot 74 \\
28 \cdot 3\end{array}$ & $\begin{array}{l}2 \cdot 34 \\
28 \cdot 2\end{array}$ & - \\
\hline Carcass water content $(\mathrm{mg} / \mathrm{g})$ & 721 & $7 \times 7$ & 694 & 699 & - \\
\hline $\begin{array}{l}\text { Ratio, water: N } \\
\text { PER } \\
\text { NPU } \\
\text { BV }\end{array}$ & $\begin{array}{l}25.5 \\
-3.19 \\
0.198 \\
0.223\end{array}$ & $\begin{array}{l}25 \cdot 3 \\
-2 \cdot 54 \\
0.209 \\
0.237\end{array}$ & $\begin{array}{l}24.8 \\
3.94 \\
0.940 \\
0.984\end{array}$ & $\begin{array}{l}24 \cdot 7 \\
2 \cdot 78 \\
0.743 \\
0.768\end{array}$ & $\begin{array}{l}- \\
0.27 \\
0.0223 \\
0.0123\end{array}$ \\
\hline $\begin{array}{l}\text { Digestibility ratios: } \\
\text { Apparent } \\
\text { True }\end{array}$ & $\begin{array}{l}0.681 \\
0.759\end{array}$ & $\begin{array}{l}0.738 \\
0.816\end{array}$ & $\begin{array}{l}0.937 \\
0.984\end{array}$ & $\begin{array}{l}0.864 \\
0.946\end{array}$ & $\begin{array}{l}0.0129 \\
0.0148\end{array}$ \\
\hline
\end{tabular}

PER, protein efficiency ratio; NPU, net protein utilization; BV, biological value.

pulp were significantly lower $(P<0.05)$ than those for either egg or casein. The bean seed with pulp was significantly better $(P<0.05)$ digested than the bean seed.

Rats receiving diets containing the two forms of the African locust bean consumed significantly less diet than those receiving either the egg- or casein-containing diets.

The bean-seed samples (both the seed and the seed with pulp) did not support the 
growth of rats. All rats given these two protein sources lost weight, giving negative PER values $(-3.19$ and -2.54$)$. NPU and BV were also low (0.198, 0.223;0.209, 0.237 respectively).

Expt 2

Chemical composition. The chemical compositions of bean seeds, with and without testa are given in Table 2. Removal of the testa resulted in an increase in crude protein content from 298.6 to $425 \mathrm{~g} / \mathrm{kg}$, a higher gross energy content, increased diethyl ether-extractable fraction and a lowering of the crude fibre content from I 15.5 to $36 \cdot 4 \mathrm{~g} / \mathrm{kg}$. The mineral contents were unchanged when the testa was removed.

Protein quality. Table 5 summarizes the protein quality of variously treated African locust-bean seeds in the rat. The egg sample was significantly better digested $(P<$ 0.005 ) than any form of the bean seeds, though the apparent and true digestibility values for the cooked sample with the testa removed were significantly higher $(P<0.05)$ than those for samples with testa. The bean seed cooked without testa and the fermented beans were significantly better digested than the raw seed without testa, though cooking caused no significant improvement in the digestibility of the raw bean with testa.

All rats given the various forms of the African locust bean lost weight during the Io $d$ period. The magnitude of the losses, however, varied with the different forms. The rats receiving the bean seed cooked without testa lost significantly less $(P<0.05)$ weight than any of the other groups. The weight losses of the other groups did not differ significantly. Food intake, and therefore protein intake, was significantly lower for rats given the various forms of the locust bean than for those given whole egg. However, rats receiving the bean seed cooked without testa consumed significantly more food and therefore more total protein than the rats given the other forms of the bean seed. All forms of the bean seed gave negative PER and low BV values. NPU values were below 0.3 except for that of the cooked sample without testa, which was significantly higher.

\section{Expt 3}

Table 6 summarizes the results obtained when the various forms of the African locust-bean seed were supplemented with amino acids.

Addition of DL-methionine alone or DL-methionine + L-tryptophan resulted in a highly significant increase $(P<0.005)$ in the total food intake and therefore also a highly significant increase in protein consumption in all groups of rats, compared with the noticeably low food intakes of rats given the unsupplemented locust-bean samples.

Addition of DL-methionine alone resulted in a highly significant increase $(P<0.005)$ in growth rate of rats given all samples of the bean seed. The highest weight gains were obtained with the bean seed cooked without testa, but these were not significantly higher than those obtained with the bean seed cooked with testa + DL-methionine. Addition of DL-methionine resulted in positive PER values, the value for the samples cooked without testa being rather higher (though not significantly so) than that of the sample cooked with testa, which was in turn significantly higher than that for the raw beans. The unsupplemented diets caused losses in weight similar to those found in 


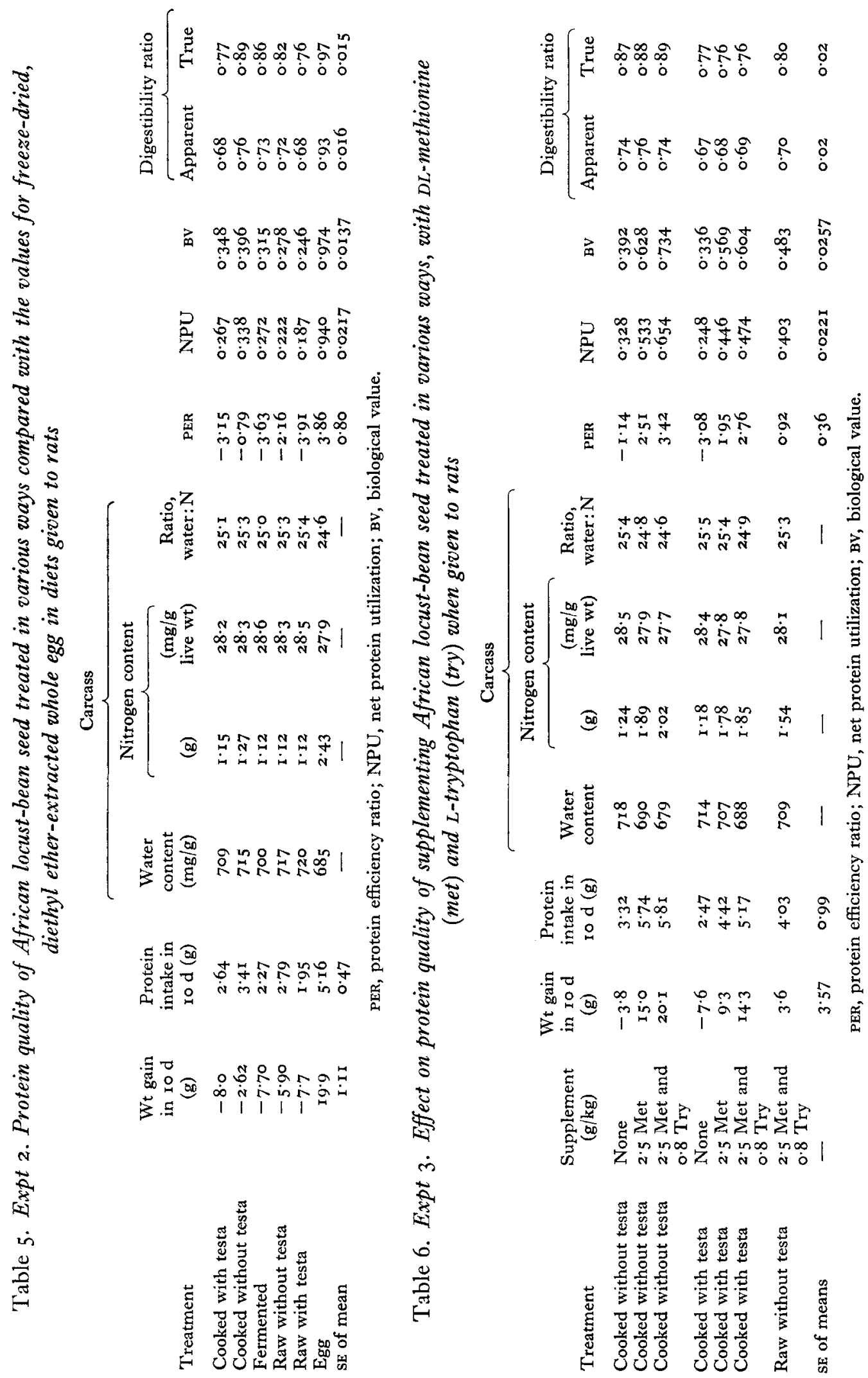


Expt I. Addition of L-tryptophan together with DL-methionine resulted in a further non-significant increase in weight gain, which was highest for the sample cooked without testa. Weight gains obtained with beans cooked with testa which were supplemented with both tryptophan and methionine were lower (though not significantly so) than those found with the samples without testa, but were very highly significantly higher than those obtained with the unsupplemented sample. The raw bean seed without testa, supplemented with $(\mathrm{g} / \mathrm{kg}) 2.5 \mathrm{DL}$-methionine and $0.8 \mathrm{~L}$-tryptophan, gave relatively slight gains, which were very highly significantly less than those for either of the cooked samples.

PER, NPU and BV also increased when samples were supplemented with tryptophan and methionine. Addition of synthetic amino acids to test diets did not appear to affect the apparent and true digestibilities of $\mathrm{N}$ in any of the samples. The digestibilities of samples in which the testa had been removed were significantly higher than those of samples in which the tough leathery testa was present.

\section{DISCUSSION}

In the three related experiments, results of proximate analysis showed that the bean seeds had some food value, though they contained large amounts of crude fibre, which are undesirable in the feeding of simple-stomached animals with a poor capacity for handling fibrous diets. Removal of the testa resulted in higher crude protein and gross energy values and an increased digestibility, probably associated with a decrease in the crude fibre content of the bean seed from i i 5.5 to $36.4 \mathrm{~g} / \mathrm{kg}$.

Although there was a noticeable improvement in the utilization of the protein of the bean seeds as a result of cooking and removal of testa, weight losses and low values for protein quality measurements were still found, indicating that, although the digestibility of the protein was low, the deficiencies of the bean in some of the essential amino acids may have been the largest factor implicated in the low values found.

The African locust-bean seed contains lysine at a level similar to that in whole egg, but its utilization is likely to be impaired by insufficiency of other essential amino acids, particularly methionine and tryptophan. The results obtained for the beans supplemented with amino acids (Table 6) tend to support this view. It could also be suggested that a high lysine content per se may accentuate the imbalance of amino acids in the bean-seed protein, particularly because of the low concentrations of the first and second limiting amino acids.

One fact is clearly shown by the results shown in Table 6 . The response to the various processed forms of the African locust-bean seed varied, although additions of DL-methionine or DL-methionine + L-tryptophan were the same. One important difference between the two forms of the cooked bean-seed samples is in their fibre content, and removal of the testa in one sample resulted in a big increase in crude fibre content. The difference in utilization of the amino acids from the intact protein and of those added as supplements to these two samples resulted in different protein quality values which might be associated with the difference in their fibre contents. This observation tends to strengthen the view that the poorer digestibility of the bean seed 
with testa may account in part for the impaired protein value observed. Impaired release of amino acids from beans with testa could indicate that the added amino acid supplements, which are more readily absorbed, are made available faster than those from the intact protein at the sites of body tissue synthesis and may be subject to wasteful deamination before the arrival of the amino acids from the intact proteins, since the body is incapable of storing amino acids. Zimmerman-Nielsen \& Schønheyder (r962) and Rolls (1970) have shown that free amino acids are more readily absorbed than those from intact proteins.

We also observed that the raw bean seed, when supplemented with synthetic methionine and tryptophan, was utilized much less efficiently than the cooked forms, with or without testa. This indicates that there are other factors hindering the utilization of amino acids in the raw bean, apart from a low digestibility and a deficit of methionine and tryptophan. One factor that immediately comes to mind is the possible presence of some toxic or potentially toxic factors or inhibitors in the raw bean seed. Oyenuga (1968), however, reported that no part of the fruit has been shown to contain cyanogenetic glycosides. It is quite possible, however, that, as in most legumes, some haemagglutinins or trypsin inhibitors are present in the raw seed. Several workers, including Oyenuga (1968) and Owusu-Domfeh (1967) have shown that most raw legumes are poorly utilized and that cooking improves their utilization.

\section{REFERENCES}

Association of Official Analytical Chemists (r970). Official Methods of Analysis i th ed. Washington, DC: Association of Official Analytical Chemists.

Bender, A. E. \& Doell, B. H. (1957). Br. F. Nutr. Ir, 140.

Duncan, D. B. (1955). Biometrics xx, x.

Miller, D. S. (1963). Publs Natn. Res. Coun., Wash. no. I 100.

Miller, E. L. (1967). Y. Sci. Fd Agric. 18, 38r.

National Academy of Sciences/National Research Council (1963). Publs Natn. Res. Coun., Wash. no. II 100 .

Owusu-Domfeh, K. (1967). Nutritive value of some Ghanaian feedstuffs. MSc Thesis, University of Saskatchewan.

Oyenuga, V. A. (1968). Nigeria's Feeds and Feedingstuffs 3rd ed. Ibadan: University Press.

Rippon, W. P. (1959). Br. F. Nutr. 13, 243.

Rolls, B. A. (1970). Factors influencing the digestion and absorption of protein in the rat. PhD Thesis, University of Reading.

Steel, R. G. D. \& Torrie, J. H. (1960). Principles and Procedures of Statistics p. 99. New York, Toronto and London: McGraw-Hill Book Co. Inc.

Zimmerman-Nielsen, C. \& Schønheyder, F. (1962). Biochim. biophys. Acta 63, 201. 